Journal of Aquaculture and Fish Health Vol. 8 No.3 (2019)

\title{
PEMBESARAN UDANG VANAME (Litopenaeus vannamei) DI PT. DEWI LAUT AQUACULTURE GARUT JAWA BARAT
}

\section{Pacific White Shrimp (Litopenaeus vannamei) Grow out in Dewi Laut Aquaculture Garut West Java}

Kurniawan Wahyu Hidayat ${ }^{1 *}$, Ighfirlii Amatullah Nabilah ${ }^{1}$, Siti Nurazizah ${ }^{1}$ dan Bobby Indra Gunawan ${ }^{2}$ ${ }^{1}$ Program Studi Budidaya Ikan, Politeknik Kelautan dan Perikanan Pangandaran, Pangandaran ${ }^{2}$ PT. Dewi Laut Aquaculture, Garut

*iwan.wh@gmail.com

\begin{abstract}
Abstrak
Udang Vaname (Litopenaeus vannamei) merupakan salah satu jenis udang yang memiliki prospek dan profit yang menjanjikan. Hal ini ditunjukkan oleh harga dan permintaan yang relatif tinggi dari tahun ke tahun. Dalam kegiatan budidaya udang vaname harus memperhatikan segala aspek mulai dari persiapan lahan sampai dengan saat panen. Dengan berkembangnya teknologi, kegiatan budidaya udang vaname dilakukan dengan teknologi dan inovasi baru yaitu budidaya udang vaname supra intensif. Kegiatan budidaya supra intensif adalah mengimplementasikan sistem budidaya yang konsisten dan terkontrol, yaitu dengan menggunakan benih yang bermutu, nutrisi yang cukup, dan dikelola dengan manajemen modern. Tujuan dari penelitian ini adalah untuk mengetahui proses kegiatan pembesaran udang vaname di PT. Dewi Laut Aquaculture dari mulai persiapan lahan, sterilisasi, pembentukan air, penebaran benur, pemeliharaan sampai panen. Metode yang digunakan dalam penelitian ini adalah dimulai dari persiapan lahan sampai dengan panen. Dari hasil pemeliharaan selama 65 hari menghasilkan panen dengan SR 85,05\%, biomassa1504,14 kg dengan ABW 6,41g/ekor. Kualitas air yang diukur selama penelitian masih dalam kisaran yang optimal bagi pertumbuhan udang yaitu suhu air $\left({ }^{\circ} \mathrm{C}\right) 28-30, \mathrm{pH} 7,5$ - 8,5, DO 4,78 - 7,30, serta amonia 0,01 - 0,21 mg/L. Dikarenakan terindikasi Infectious Myonecrosis Virus (IMNV), maka udang dipanen lebih awal.
\end{abstract}

Kata kunci: Teknik Budidaya, Pembesaran, Intensif, Udang Vaname, Litopenaeus vannamei

\section{Abstract}

Pacific white shrimp (Litopenaeus vannamei) one of the species that good both prospect and profit. It showed in demand and price rate for this shrimp is relatively high, year by year. In aquaculture practices, must concern all about the aspect, start from land or pond preparation, feeding to harvesting method. Technology improvement affects shrimp aquaculture. One of that technology is a huge stocking density, commonly called supra-intensive. This aquaculture method, implementing all systems under control and consistent operating procedure, by using high-grade seeds, adequate nutrition, and manage by modern management. The aim of this study to understand all aquaculture processes, especially Pacific white shrimp grow out in PT. Dewi Laut Aquaculture. It started from land preparation, sterilization, water treatment, stocking, grows out until its harvest. This study takes part in all work schedules from the company. The result showed that after 65 days of culture, harvested $85,05 \%$ Survival rate, $1504,14 \mathrm{~kg}$ biomass, with $6,41 \mathrm{~g}-1 \mathrm{ABW}$. Water quality showed that water temperature $\left({ }^{\circ} \mathrm{C}\right) 28-30, \mathrm{pH} 7,5-8,5$, Dissolved Oxygen 4,78 - 7,30, and ammonia 0,01-0,21 $\mathrm{mg} / \mathrm{L}$. Duet o indication of Infected Infectious Myonecrosis Virus (IMNV), the shrimp is harvested earlier.

Keywords : Culture technique, Growout, Intensive, Pacific white shrimp, Litopenaeus vannamei

\section{PENDAHULUAN}

Budidaya merupakan salah satu kegiatan dalam meningkatkan produksi perikanan. Udang vaname Litopenaeus vannamei merupakan salah satu komoditas unggulan dalam budidaya perikanan. Hal ini karena selain harganya kompetitif, sistem produksinya juga dapat dilakukan secara masal dengan padat tebar tinggi (Mangampa dan Suwono, 2016).

\begin{abstract}
Permintaan udang vaname sangat besar baik pasar lokal maupun internasional, karena memiliki keunggulan nilai gizi yang sangat tinggi serta memiliki nilai ekonomis yang cukup tinggi menyebabkan pesatnya budidaya udang vaname (Mahbubillah, 2011). Kebutuhan masyarakat dunia terhadap protein hewani ikan terus meningkat seiring dengan peningkatan populasi penduduk dunia.
\end{abstract}


Sejak tahun 1990-an, tren produksi perikanan tangkap mengalami stagnasi dan cenderung menurun akibat kerusakan lingkungan laut dan upaya penangkapan ikan ilegal dengan menggunakan alat tangkap yang tidak ramah lingkungan. Oleh karena itu sektor budidaya diharapkan dapat menjadi solusi dalam pemenuhan konsumsi ikan dunia (Yustianti et al., 2013).

Berbagai kelebihan, dimiliki oleh udang vaname yaitu antara lain sistem budidaya relatif mudah, tahan terhadap penyakit, baik bakteri maupun virus, udang ini juga mampu dipelihara dengan salinitas yang rendah (Kaligis, 2015). Teknologi budidaya udang vaname semakin berkembang dengan lahirnya teknologi intensif dan supra intensif mencapai padat tebar yang tinggi berkisar $100-400 \mathrm{ekor} / \mathrm{m}^{2}$ (Nababan et al., 2015).

Tambak intensif adalah tambak yang dilengkapi dengan plastik mulsa yang menutupi semua bagian, pompa air, kincir air, aerator, tingkat penebaran tinggi dan pakan 100\% pelet. Menurut Atjo (2013) tambak supra-intensif adalah tambak yang memiliki luasan $1000 \mathrm{~m}^{2}$ dengan kepadatan 312-1000 ekor $/ \mathrm{m}^{2}$. Pakan merupakan sumber nutrisi yang terdiri dari protein, lemak, karbohidrat, vitamin dan mineral yang dibutuhkan udang untuk pertumbuhan dan perkembangan secara optimal sehingga produktivitasnya bisa ditingkatkan (Panjaitan, 2013).

Tujuan penelitian ini adalah untuk mengetahui kinerja produksi dan kualitas air pada tambak PT Dewi Laut Aquaculture, blok B (B3 dan B4) yang berluasan masingmasing $400 \mathrm{~m}^{2}$.

\section{METODOLOGI \\ Waktu dan Tempat}

Kegiatan penelitian pembesaran udang vaname (Litopenaeus vannamei) dilaksanakan pada tanggal 01 November 31 Desember 2018. yang bertempat di tambak PT. Dewi Laut Aquaculture, Jln. Raya Lintas selatan Dusun Cicadas, Desa Cigadog, Kecamatan Cikelet, Kabupaten Garut, Jawa Barat.

\section{Materi Penelitian}

Alat-alat yang digunakan dalam penelitian ini adalah kolam pemeliharaan, kincir, blower, plastik High-Density Poly Ethylene (HDPE), pemeriksaan kualitas air, sampling pertumbuhan, dan pemanenan. Bahan yang digunakan dalam penelitian ini adalah benur udang vaname dan pakan.

\section{Rancangan Penelitian}

Penelitian ini meliputi observasi, wawancara, dokumentasi, studi pustaka, dan mengikuti secara langsung kegiatan budidaya udang vaname (Litopenaeus vannamei) di PT. Dewi Laut Aquaculture.

\section{Prosedur Kerja}

Perusahaan mempunyai Standard Operating Procedure (SOP) yang jelas mengenai seluruh proses budidaya udang vaname seperti terlihat pada Gambar 1.

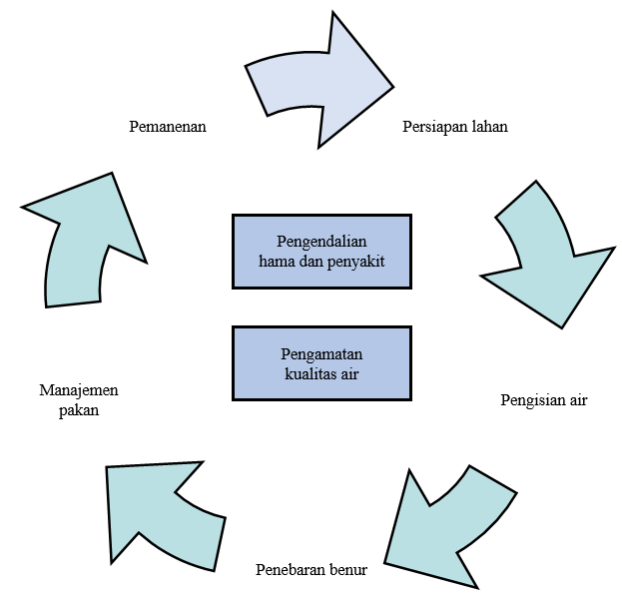

Gambar 1. Diagram pengelolaan tambak di PT. Dewi Laut Aquaculture. 
Kegiatan penelitian di PT. Dewi Laut Aquaculture dibagi menjadi beberapa tahap antara lain, persiapan lahan yang meliputi pembersihan kolam, perbaikan kolam, setting kincir dan blower. Dilanjutkan dengan pengisian air, pembentukan air, penebaran benur, pemberian pakan, pengamatan kualitas air, monitoring hama dan penyakit, dan pemanenan.

\section{Analisis Data}

Jurnal disusun dengan metode deskriptif, yang dilanjutkan dengan studi pustaka untuk membandingkan antara teori dengan praktik di lapangan.

\section{HASIL DAN PEMBAHASAN \\ Pembersihan Kolam}

Tahap pembersihan kolam dilakukan dengan cara mengelilingi kolam yang akan dibersihkan dan mengambil benda-benda yang masih ada dalam kolam. Membersihkan kolam dari sisa-sisa pakan, lumpur atau kotoran udang setelah panen dengan cara menyikat dan menyiram kolam. Sterilisasi dilakukan dengan menggunakan Trichloroisocyanuric acid (TCCA) $90 \%$ dosis $60 \mathrm{ppm}$ dengan tujuan membunuh mikroorganisme yang ada di air.

Proses perbaikan kolam dimulai dari memastikan, menandai dan menambal plastik HDPE di kolam, dilanjutkan dengan mengelilingi kolam untuk mencari plastik HDPE yang berlubang. Memberi tanda pada plastik HDPE yang berlubang menggunakan batang lidi atau benda yang dapat digunakan sebagai penanda. Setelah proses penandaan dilakukan penambalan plastik HDPE yang berlubang. Penambalan plastik HDPE di kolam menggunakan plastik HDPE yang ukurannya di sesuaikan dengan kondisi lubang, dengan uap panas.

\section{Setting Kincir dan Blower}

Untuk memastikan suplai oksigen yang merata perlu dilakukan persiapan pemasangan kincir dan blower dengan cara meletakan blower di rumah blower, dilanjutkan dengan pemasangan blower ke kolam yaitu dengan menyambungkan pipa- pipa yang berada di dasar kolam. Pemasangan pipa di dasar membentuk segi empat seperti bentuk kolam, kemudian pipa-pipa tersebut diberi lubang kecil untuk keluarnya udara (diffuser), selanjutnya adalah pemasangan kincir, yang ditempatkan di bagian sudut-sudut kolam dan berbentuk segi empat sesuai dengan bentuk kolam yaitu persegi, menggunakan 4 kincir. Pengoperasian kincir dilakukan sepanjang hari, sedangkan blower dioperasikan bergantian dari pagi ke sore dan dari sore ke malam.

\section{Pengisian Air}

Tahap pengisian air ke kolam budidaya mengikuti prosedur yaitu pengisian kolam menggunakan air dari tandon, pengisian awal air di kolam budidaya hanya sampai $150 \mathrm{~cm}$. Setelah pengisian air dilakukan sterilisasi air, dengan menggunakan Trichloroisocyanuric acid (TCAA) 90\% dengan dosis $60 \mathrm{ppm}$, proses ini bertujuan untuk membunuh mikroorganisme yang berada di dalam air. TCCA yang digunakan pada kolam berluasan $400 \mathrm{~m}^{2}$. Selain menggunakan TCCA, untuk disinfektan juga menggunakan Biofectan ${ }^{\circledR}$ sebanyak 2,5 ppm per kolam.

\section{Pembentukan Air}

Pembentukan air dalam hal ini adalah proses menumbuhkan plankton, bakteri dan meningkatkan mineral. Dimulai dari pemupukan dengan pupuk ZA sebanyak 2 ppm. Selanjutnya dilakukan pemberian cairan fermentasi yang sudah dipersiapkan dari bahan-bahan antara lain, bungkil kedelai, dedak, molase, ragi dan air bersih. Selain fermentasi untuk meningkatkan bakteri baik, juga dilakukan aplikasi probiotik, yang diharapkan memberikan efek positif bagi udang baik itu pertumbuhan, sintasan maupun FCR (Sambasivam et al., 2003).

PT. Dewi Laut Aquaculture menggunakan dua merek probiotik yaitu QuickPro Direct ${ }^{\mathbb{B}}$ dan Tionat Direct ${ }^{\circledR}$. Untuk meningkatkan $\mathrm{pH}$ dilakukan dengan 
penambahan $\mathrm{CaCO}_{3}$ dan $\mathrm{Ca}(\mathrm{OH})_{2}$ masing masing sebanyak 10 ppm. Sebagai disinfektan juga ditambahkan $\mathrm{H}_{2} \mathrm{O}_{2}$ sebanyak $2 \mathrm{ppm} /$ kolam. Untuk memberantas ikan-ikan liar digunakan larutan saponin sebanyak $25 \mathrm{ppm}$.

\section{Penebaran Benur}

Proses penebaran benur dilakukan dalam tiga tahap yaitu pengecekan kualitas air, perhitungan benur, dan aklimatisasi. Benur ditebar pada pagi atau sore hari, pengecekan kualitas air yang diukur adalah air kolam dan air paking benur dengan parameter antara lain suhu, $\mathrm{DO}, \mathrm{pH}$ dan salinitas. Dilanjutkan dengan perhitungan benur dengan tahapan, mengambil dua atau tiga plastik benur yang akan di tebar, lalu hitung menggunakan hand tally counter di laboratorium, kemudian catat data benur yang terhitung dalam semua sampel plastik benur yang diambil. Jumlah benur yang ditebar pada kolam B3 dan B4 adalah 196.150 ekor atau dengan kepadatan $490 / \mathrm{m}^{2}$.

Benur yang digunakan berasal dari PT. Suri Tani Pemuka Carita, Banten dengan ukuran PL 8 - PL 12. Aklimatisasi benur di perusahaan ini menggunakan sistem "konikel" yaitu aklimatisasi dilakukan di bak terpisah tidak langsung di kolam, namun dengan prinsip yang sama yaitu menyamakan keadaan di bak dengan keadaan pada kolam sebelum akhirnya benur ditebar.

\section{Pemberian Pakan}

Pakan diberikan saat benih berusia satu hari (DOC 1). Dalam satu hari pakan diberikan sebanyak empat kali Sesi 1, jam 06:30 WIB dengan persentase $22 \%$, sesi 2 , jam 10:30 WIB dengan persentase 28\%, sesi 3, jam 14:30 WIB dengan persentase $28 \%$, sesi 4, jam 18:30 WIB dengan persentase $22 \%$, jenis pakan yang digunakan DOC $1-15$, menggunakan powder (Bubuk) - Irawan $682 \mathrm{~V}$ Protein $30 \%$, DOC 16 - 30, crumble (Bubuk lebih kasar, lebih besar dari Powder) - Irawan SA01 Protein 30\%, DOC 31 - panen, pellet (Sudah terbentuk seperti silinder, tidak bubuk) - Irawan 683 SP Protein 30\%.

\section{Pengamatan Kualitas Air}

Kualitas air yang diamati antara lain Oksigen terlarut (DO) menggunakan DO meter, $\mathrm{pH}$ menggunakan $\mathrm{pH}$ meter, suhu menggunakan termometer, dan amonia menggunakan spektrofotometer. Hasil pengamatan harian kualitas air ditampilkan dalam Tabel 1.

Tabel 1. Pengukuran kualitas air.

\begin{tabular}{|c|c|c|c|}
\hline \multirow{2}{*}{ Parameter } & \multicolumn{2}{|c|}{ Kolam } & Pustaka \\
\hline & B3 & B4 & (SNI 8037.1:2014) \\
\hline Suhu $\left({ }^{\circ} \mathrm{C}\right)$ & $20-30$ & $28-30$ & $28-33$ \\
\hline $\mathrm{pH}$ & $7.5-8.8$ & $7.5-8.5$ & $7.5-8.5$ \\
\hline $\mathrm{DO}(\mathrm{mg} / \mathrm{L})$ & $4.78-7.30$ & $4.78-7.30$ & $3.0-7.5$ \\
\hline Amonia $(\mathrm{mg} / \mathrm{L})$ & $0.01-0.21$ & $0.01-0.21$ & $<0.1$ \\
\hline
\end{tabular}

\section{Monitoring Hama dan Penyakit}

Berdasarkan hasil pengamatan kualitas air diperoleh bahwa kualitas air pada kolam B3 dan B4 masih sesuai untuk pemeliharaan udang vaname (SNI 8037.1.2014), untuk parameter amonia kadar amonia pada kolam B3 dan B4 yaitu $0,01-0,21 \mathrm{mg} / \mathrm{L}$. Amonia pada kedua kolam melebihi standar amonia budidaya udang vaname menurut (SNI 8037.1:2014), akibat berlebih amonia maka dapat meningkatkan penggunaan oksigen pada jaringan, merusak insang, dan menurunkan kemampuan darah dalam mengangkut oksigen (Boyd, 1982).

Hama yang terdapat di tambak PT. Dewi Laut Aquaculture yaitu biawak, kepiting, ular, dan siput laut. Sedangkan penyakit yang terindikasi yaitu Infectious Myonecrosis Virus (IMNV), udang yang 
terserang IMNV mempunyai ciri-ciri insang menghitam, otot putih dan ekor kemerahan, hal tersebut sesuai dengan Rekasana et al. (2013) yang menyatakan bahwa Karakteristik serangan IMNV secara patologi ditandai dengan adanya nekrosis yang tampak secara kasat mata berwarna putih pada daging udang vaname dan berlanjut ke warna merah pada bagian ekor kipas dan 2 ruas abdomen terakhir (Gambar 2).

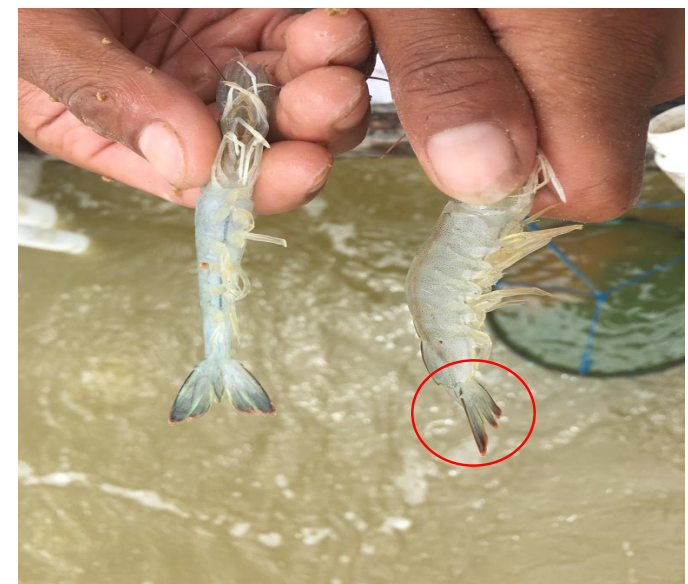

Gambar 2. Udang yang terserang Infectious Myonecrosis Virus (IMNV).

\section{Pemanenan}

Pemanenan yang dilakukan di PT. Dewi Laut Aquaculture dilakukan dengan menggunakan sistem panen parsial dan panen total. Panen parsial dilakukan dengan menangkap udang menggunakan jala, panen parsial tersebut dilakukan saat udang berada pada umur 65 dengan size 107 dan hasil size ini diketahui setelah dilakukan sampling.
Setelah dilakukan panen parsial selanjutnya dilakukan panen total. Pemanenan total ini dilakukan dengan cara membuka pintu pada tambak yang terbuat dari besi, dan di saluran pintu tersebut diberi waring supaya udang tidak berserakan. Hasil produksi blok B dapat dilihat pada Tabel 2.

Tabel 2. Hasil produksi blok B.

\begin{tabular}{lrrr}
\hline \multicolumn{1}{c}{ Parameter } & \multicolumn{1}{c}{ Kolam } & \multicolumn{1}{c}{ Rerata } \\
\hline SR (\%) & 71,70 & 98,40 & 85,05 \\
Biomassa (Kg) & 847,20 & $1.313,88$ & $1.504,14$ \\
ABW (g/ekor) & 6,02 & 6,80 & 6,41 \\
\hline
\end{tabular}

\section{KESIMPULAN DAN SARAN \\ Kesimpulan}

Berdasarkan hasil penelitian ini dapat di tarik kesimpulan yaitu wadah yang digunakan adalah plastik HDPE, pakan yang diberikan berupa pakan alami melalui pemupukan dan pakan buatan berupa pelet, pengontrolan kualitas air selalu di pantau baik fisik, kimia maupun biologi, pertumbuhan udang vaname di kolam B3 dan B4 berbeda dan walaupun dengan system budidaya yang sama. Proses budidaya udang pada siklus ini terganggu oleh adanya penyakit Infectious Myonecrosis Virus (IMNV) dengan ciri secara kasat mata warna daging putih dan ekor berwarna merah pada ujungnya. 


\section{Saran}

Adapun saran yang dapat penulis berikan kepada PT. Dewi Laut Aquaculture adalah: Perlunya peningkatan pengawasan kinerja terhadap karyawan, agar semua dapat berjalan lancar sesuai dengan prosedur. Perlu adanya proses pengolahan air buangan agar tidak mencemari lingkungan tambak sekitar. Perlunya penerapan biosecurity yang baik untuk menghindari kontaminasi yang dapat terjadi.

\section{DAFTAR PUSTAKA}

Atjo, H., 2013. Budi daya udang vaname supra-intensif Indonesia. Dipresentasikan pada Launching Budi Daya Udang Vaname Super Intensif Indonesia. Barru, 24.

Boyd, C.E., 1982. Water quality management for pond fish culture. Elsevier Scientific Publishing Co.

Dewi Laut Aquaculture, PT. 2017. Profil PT. Dewi Laut Aquaculture di (READY) website https://www.dewilaut.com/ diakses pada [24 April 2019].

Kaligis, E., 2015. Respons Pertumbuhan Udang Vaname (Litopenaeus vannamei) di Media Bersalinitas Rendah dengan Pemberian Pakan Protein dan Kalsium Berbeda. Jurnal Ilmu dan Teknologi Kelautan Tropis, 7(1), pp. 225-234.

Mahbubillah, M.A., 2011. Budidaya Udang Vannamei. On line at http://marinebiologi.blogspot.com/.

Mangampa, M. dan Suwoyo, H.S., 2016. Budidaya Udang Vaname (Litopenaeus vannamei) Teknologi Intensif Menggunakan Benih Tokolan. Jurnal Riset Akuakultur, 5(3), pp.351-361.

Nababan, E., Putra I. dan Rusliadi, 2015. Pemeliharaan udang vaname (Litopenaeus vannamei) dengan persentase pemberian pakan yang berbeda. Jurnal Ilmiah Perikanan dan Kelautan, 3(2).
Panjaitan, A.S., 2013. Pemeliharaan larva udang vaname (Litopenaeus vannamei, boone 1931) dengan pemberian jenis fitoplankton yang berbeda (Doctoral dissertation, Universitas Terbuka).

Rekasana, A., Sulmartiwi, L. dan Sudarno, 2013. Distribusi Penyakit Infectious Myo Necrosis Virus (IMNV) Pada Udang Vannamei (Litopenaeus vannamei) Di Pantai Utara Jawa Timur [Distribution Of Infectious Myo Necrosis Virus (IMNV) In White Shrimp Vannamei (Litopenaeus vannamei) In North Coast, East Java]. Jurnal Ilmiah Perikanan dan Kelautan, 5(1), pp.4954.

Standar Nasional Indonesia. 2014. Udang Vaname (Litopenaeus vannamei, Boone 1931) Bagian 1: Produksi Induk Model Indoor (SNI 8037.1:2014)

Yustianti, I.M., Ibrahim, N. dan Ruslaini, 2013. Pertumbuhan dan Sintasan larva udang Vaname (Litopenaeus vannamei) Melalui Substitusi Tepung Ikan dengan Tepung Usus Ayam. Jurnal Mina Laut Indonesia, 1(1), pp.93-103. 